Journal of Applied Pharmaceutical Science Vol. 6 (06), pp. 131-138, June, 2016

Available online at http://www.japsonline.com

DOI: $10.7324 /$ JAPS.2016.60623

ISSN 2231-3354 (cc) BY-NC-SA

\title{
Effect of Arbuscular mycorrhizal fungi (AMF) and Azospirillum on growth and nutrition of banana plantlets during acclimatization phase
}

\author{
Villarreal Tania Carina ${ }^{1}$, Medina María Emilia ${ }^{1 *}$, Ulloa Santiago Miguel $^{2}$, Darwin Rueda Ortiz ${ }^{1}$, Bangeppagari \\ Manjunatha ${ }^{1}$, Selvaraj Thangaswamy ${ }^{3}$, Sikandar I. Mulla ${ }^{4}$ \\ ${ }^{1}$ Department of Life Sciences, Universidad de las Fuerzas Armadas-ESPE, Sangolquí, POBOX: 171-5-231B, Ecuador, South America. ${ }^{2}$ Career of \\ Agricultural Engineering II, Universidad de las Fuerzas Armadas-ESPE, Santo Domingo, Ecuador. ${ }^{3}$ Centre for Marine Science and Technology, \\ Manonmaniam Sundaranar Univeristy, Rajakkamangalam, Kanyakumari District, Tamil Nadu State, India. ${ }^{4}$ Department of Biochemistry, Karnatak \\ University, Dharwad, Karnataka, India.
}

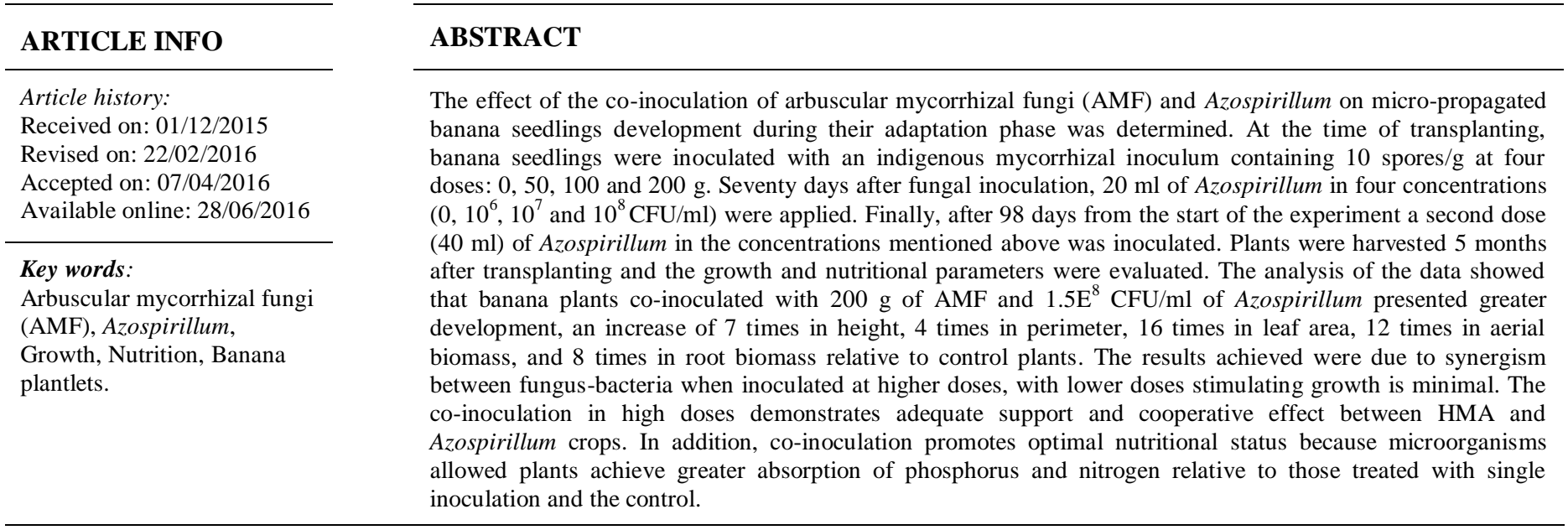

\section{INTRODUCTION}

The excellent climatic and ecological condition which owns Ecuador, have become one of the largest producers and exporters of bananas worldwide, with a cultivated area of 230,000 hectares (32\% of world production) located mainly in the provinces of El Oro, Guayas and Los Rios (AEBE, 2010). However, as in most countries where bananas are grown, the application of chemical fertilizers on a large scale has not changed throughout history. This poses an environmental

* Corresponding Author

Department of Life Sciences, Universidad de las Fuerzas Armadas-

ESPE, Sangolquí, Quito, Ecuador, South America. problem in the long term because the synthetic compounds containing nitrogen are a source of contamination of soil and groundwater; the fact that is aggravated due to the low efficiency of banana roots to absorb synthetic fertilizers. It is therefore, necessary improve the management of banana cultivation, not only to reduce the impact of agriculture on the environment, but also to improve productivity through sustainable management; using products based on own soil microorganisms fertilizers. These microorganisms are able to promote growth, productivity and maintain soil fertility. In this context, both arbuscular mycorrhizal fungi (AMF) as plant growth promoting bacteria Azospirillum genus have been studied as a great adaptability to environmental conditions and soil of banana plantations (Loredo et al., 2004). 
Arbuscular mycorrhizae are defined as the mutual association between a fungus and the roots of the plant, where both benefit and participate actively in the uptake and translocation of nutrients (Bolan, 1991). Among the benefits that this partnership is: better uptake of nutrients and water, increased plant growth, tolerance to stress conditions and resistance to pathogens. All these benefits enable the plant to improve its ability to adapt to environmental conditions which give it a competitive advantage over non-mycorrhizal and finally its further development results in increased productivity plants (Maldonado and Ramirez, 1997).

The genus Azospirillum includes free-living bacteria (Okon and Labandera, 1994) which are distributed in temperate and tropical regions, presenting greater abundance in the latter (Döbereiner et al., 1976). Its importance lies in its potential to colonize the areas of cell elongation of roots present in the base of the root hairs (Bashan and Holguin, 1997a). These bacteria fix nitrogen and produce growth regulating hormones such as indole acetic acid, which is responsible for stimulating the formation of lateral roots and root hairs.

Bashan and Holguin (1997b) determined that Azospirillum inoculation is more successful when other microorganisms are co-inoculated. The co-inoculation with HMA has a synergistic relationship where both microorganisms grow in tandem due to involved in providing nutrients, remove inhibitory products and facilitate this process in plant development.

Although there is research in the field of co-inoculation of Azospirillum HMA and in some plant species, is very little information regarding this subject banana plants.

The objective of this experiment was to evaluate the effect of combined inoculation of HMA and Azospirillum on growth and nutrition of micro propagated banana plantlets during the acclimatization.

\section{MATERIALS AND METHODS}

\section{Biological material}

The research was conducted using in vitro banana plantlets (Var. Williams) $5 \mathrm{~cm}$ high. This biological material was provided by Plant Tissue Culture Laboratory, Universidad de las Fuerzas Armadas-ESPE. Plantlets were transplanted into 32 hozpots containing a sterile substrate composed of $30 \%$ sand, $10 \%$ black peat PROMIX PGX and 60\% black soil.

AMF spores of (Rhizophagus irregularis) isolated from root-zone soils of banana plants of Central Finance HDINEAGROS SA farm soils, Gold province were multiplied over 5 month's period in the sterilized soils of the same location. For spore's multiplication, oats (Avena sativa) plants were used as host and seeded on soil-sand $(1: 1 \mathrm{w} / \mathrm{w})$ and ground banana substrate, containing $1 \mathrm{spore} / \mathrm{g}$. At the end of one multiplication period 10 spores/g mycorrhizal inoculum was obtained.

Azospirillum (G4b) strain was selected from 8 isolates obtained in mixtures of soil and banana roots based on production capacity indole acetic acid (IAA) $(6 \mu \mathrm{g} / \mathrm{ml})$ by reagent Salkowski (BRIC et al., 1991). Azospirillum inoculum developed from axenic amid Malic Acid Red Congo and involved a bacterial suspension of sterile saline $(0.85 \% \mathrm{NaCl})$ to be adjusted to three levels: $10^{6}$, $10^{7}$ and $10^{8} \mathrm{CFU} / \mathrm{ml}$.

\section{Experimental Design and Inoculation}

For testing, 16 treatments with a factorial arrangement of two factors were used: mycorrhizal doses $(0,50$, 100 and $200 \mathrm{~g}$ ) and Azospirillum concentration (0, 106, 107 and $10^{8} \mathrm{CFU} / \mathrm{ml}$ ). Nine replicates per treatment were performed (experimental unit: 1 plant. Total 144 plants) and finally plants were organized using a completely randomized design in a growth chamber.

AMF inoculation was performed only once in the transplant and bacterial inoculation was effected twice, first dose (20 ml/plant) Azospirillum was applied at 70 days after transplantation and second (40 ml/plant) was performed at 98 days. Acclimation took five months in which the plants were kept in a growth chamber at $25^{\circ} \mathrm{C}, 90 \%$ relative humidity and Hewitt nutrient solution irrigation (during first 6 weeks). All plants were watered with distilled water according to the requirements of irrigation.

\section{Monitoring and Evaluation of the variables}

Growth variables: height, pseudostem perimeter and leaf area were monitored at 0,70 and 98 days. At 150 days final evaluation was made and additionally recorded.

Root and foliar biomass: This variable was analyzed at 150 days using general and mixed linear models. Nutrient content $(\mathrm{N}, \mathrm{P}, \mathrm{K})$ in both soil and leaf tissue, using wet mineralization for Nitrogen by the Kjeldahl method; Phosphorus and Potassium by atomic absorption method. HMA spores final population (Genderman and Nicholson, 1963, Herrera et al., 2004), mycorrhizal colonization percentage (Philips and Hayman, 1970) and Azospirillum final population in soil and banana roots.

\section{Statistical analysis}

Growth, nutrition and symbiosis variables were analyzed by InfoStat statistical software. Linear and Mixed Models with a comparison test of Fisher LSD statistical averages 5\% was used. Finally R language regression analysis was used.

\section{RESULTS AND DISCUSSION}

\section{HMA multiplication}

For large scale spores multiplication in a short time, a trap crop using host plant, soil and / or plants roots containing mycorrhiza spores are established (Bever et al., 1996). Oat plants (Avena sativa) as host planted in suitable soil and inoculated with 1 spore/g soil were used. After 5 months culture, 10 spores/g $(89.3 \%$ increases) was obtained, which were applied in banana plantlets using different doses (Figure 1). 


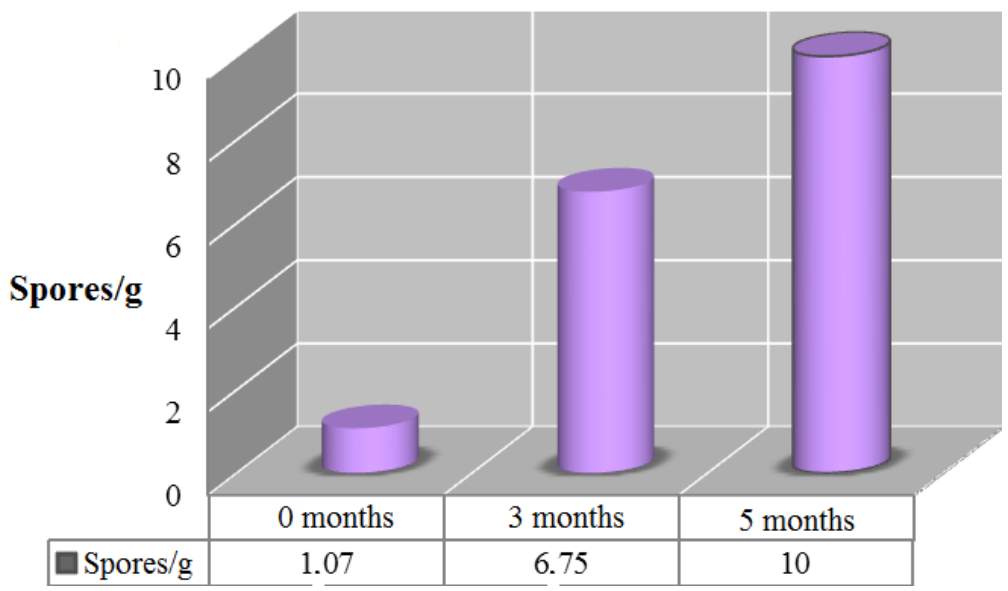

Fig. 1: Increased density of AMF spores in oats trap crop.

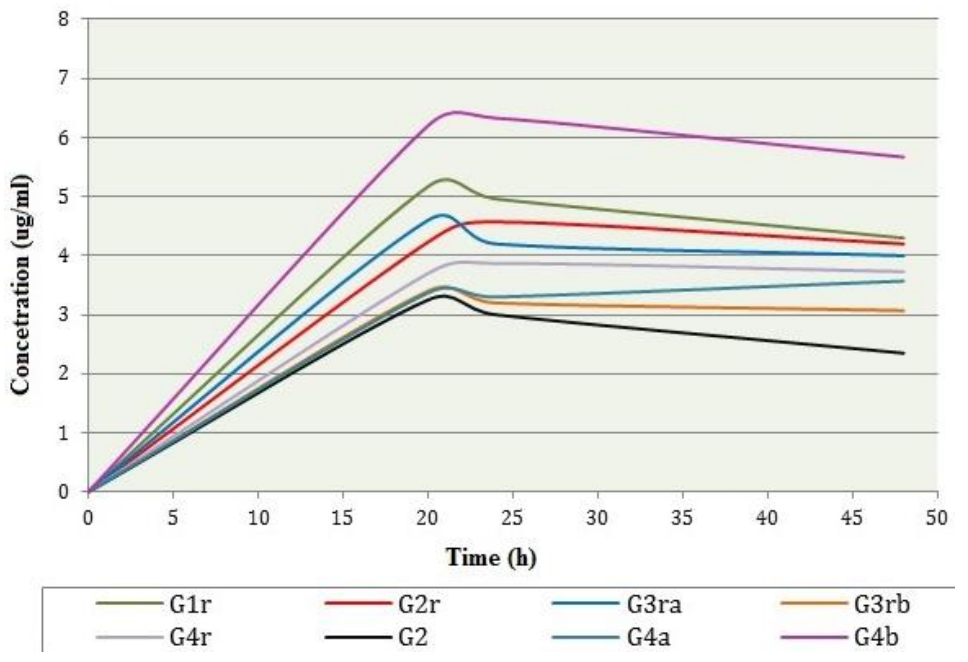

Fig. 2: IAA concentration produced by Azospirillum strains.

\section{Selecting Azospirillum strain inoculum}

Diazotrophic bacterias isolated from soil and roots were plated on solid Malic Acid Congo-red selective medium obtained strains were tested for primary and secondary biochemical identification. For selection of seed strain, we worked with identified and codified 8 strains, and with them the ability to produce IAA in tryptophan medium supplemented with different incubation times were evaluated. Results show that the maximum concentration of IAA between Azospirillum strains ranges from 2.5 to $6.33 \mathrm{ug} / \mathrm{ml}$, values within the range reported for production gender and corresponding to concentrations of 1 to $25 \mathrm{ug} / \mathrm{ml}$ (Tien et al., 1979; Crozzier et al., 1988) (Figure 2). The selected strain showed increased production of IAA $(6.33 \mathrm{ug} / \mathrm{ml})$ and corresponded to the isolation $\mathrm{G} 4 \mathrm{~b}$.

\section{Growth}

HMA simple inoculation, HMA co-inoculation and Azospirillum allowed benefits plant growth. However seedlings treated with $200 \mathrm{~g}$ of HMA and $10^{8} \mathrm{CFU} / \mathrm{ml}$ Azospirillum showed the largest increases in all evaluated growth variables. Table 1 shows the highest statistical measures. Data recorded for all growth evaluated parameters show the greatest increases in the inoculated treatment with higher doses of the two microorganisms, reaching 7 times height, 4 times perimeter and 16 times leaf area relative to control plants. Equally significant effect on plant biomass of co-inoculated banana seedlings was observed, showing 12 times foliar biomass increase and 8 times root biomass compared to the control group. In addition, regression analysis shows that the model that fits all growth variables evaluated correspond to Gompertz logistic regression. Only to analyze the data of height and perimeter a previous calculation of the growth rate was performed and it was determined that the height and width of plant is directly related to HMA amount, since mycorrhiza higher number increased leaf development. For leaf area and plant biomass HMA co-inoculation and Azospirillum are directly influenced. Highest values were recorded in $10^{8} \mathrm{CFU} / \mathrm{ml}$ of Azospirillum +200 g of HMA treatment. These results are consistent with that described by Jaizme-Vega et al. (2004) who determined that applying Glomus manihotis and Bacillus sp cocktail to banana plantlets, higher values were obtained for all growth variables evaluated for the simple inoculation with each microorganism separately and the control group (Figure 3). 
Table 1: Effect of HMA co-inoculation and Azospirillum the growth of micro propagated banana plantlets (150 days).

\begin{tabular}{|c|c|c|c|c|c|}
\hline Treatment & $\begin{array}{c}\text { Heigth } \\
(\mathbf{c m})\end{array}$ & $\begin{array}{c}\text { Perímeter } \\
(\mathrm{cm})\end{array}$ & $\begin{array}{c}\text { Leaf área } \\
\left(\mathrm{cm}^{2}\right)\end{array}$ & $\begin{array}{c}\text { Foliage Biomass } \\
(\mathrm{g})\end{array}$ & $\begin{array}{c}\text { Root Biomass } \\
\text { (g) }\end{array}$ \\
\hline Control & $1.59 \mathrm{a}$ & $0.76 \mathrm{a}$ & $12.11 \mathrm{c}$ & $4.27 \mathrm{c}$ & $4.37 \mathrm{~d}$ \\
\hline Azospirillum $\left(10^{8} \mathrm{CFU} / \mathrm{ml}\right)$ & $3.00 \mathrm{a}$ & $1.04 \mathrm{a}$ & $55.67 \mathrm{~b}$ & $4.57 \mathrm{c}$ & $7.88 \mathrm{c}$ \\
\hline HMA $(200 \mathrm{~g})$ & $9.82 \mathrm{a}$ & $2.19 \mathrm{a}$ & $158.56 \mathrm{ab}$ & $36.59 \mathrm{~b}$ & $20.37 \mathrm{~b}$ \\
\hline Azospirillum + HMA $\left(10^{8} \mathrm{UFC} / \mathrm{ml}+200 \mathrm{~g}\right)$ & $10.83 \mathrm{a}$ & $2.68 \mathrm{a}$ & $193.44 \mathrm{a}$ & $51.07 \mathrm{a}$ & $34.82 \mathrm{a}$ \\
\hline
\end{tabular}

In the same column, data with the same letter have no statistical differences according to Fisher LSD test at $5 \%$ (p $\leq 0.05$ ).
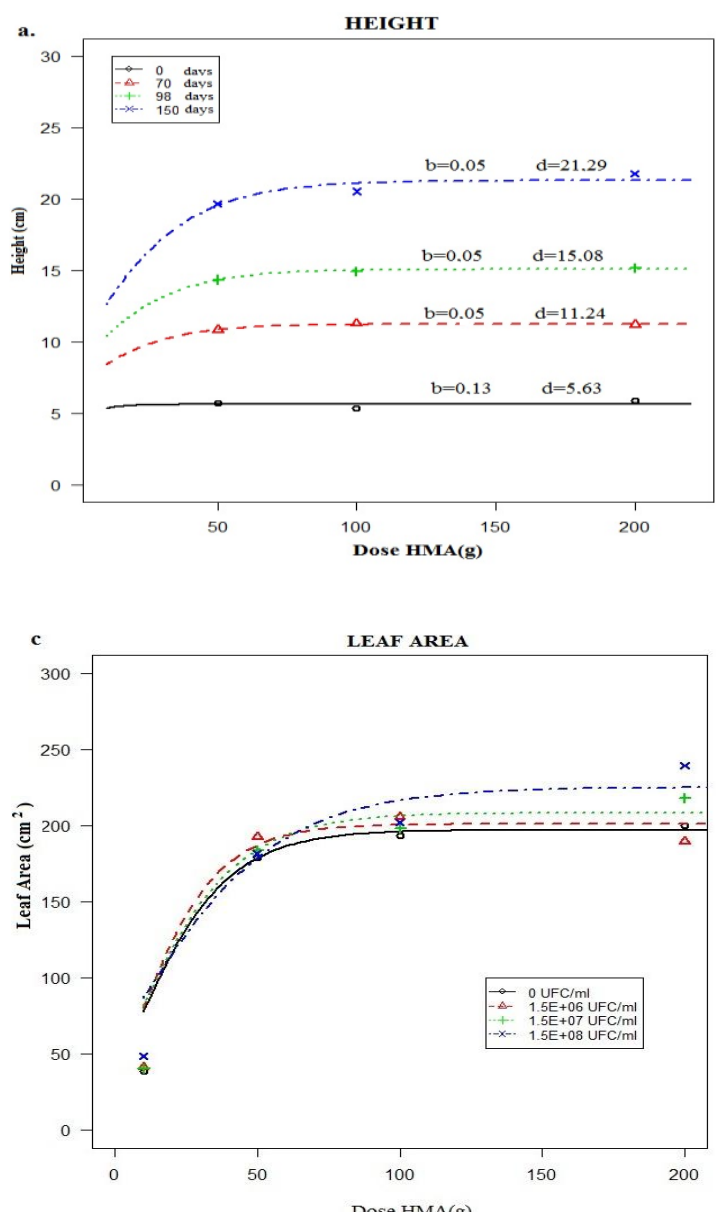
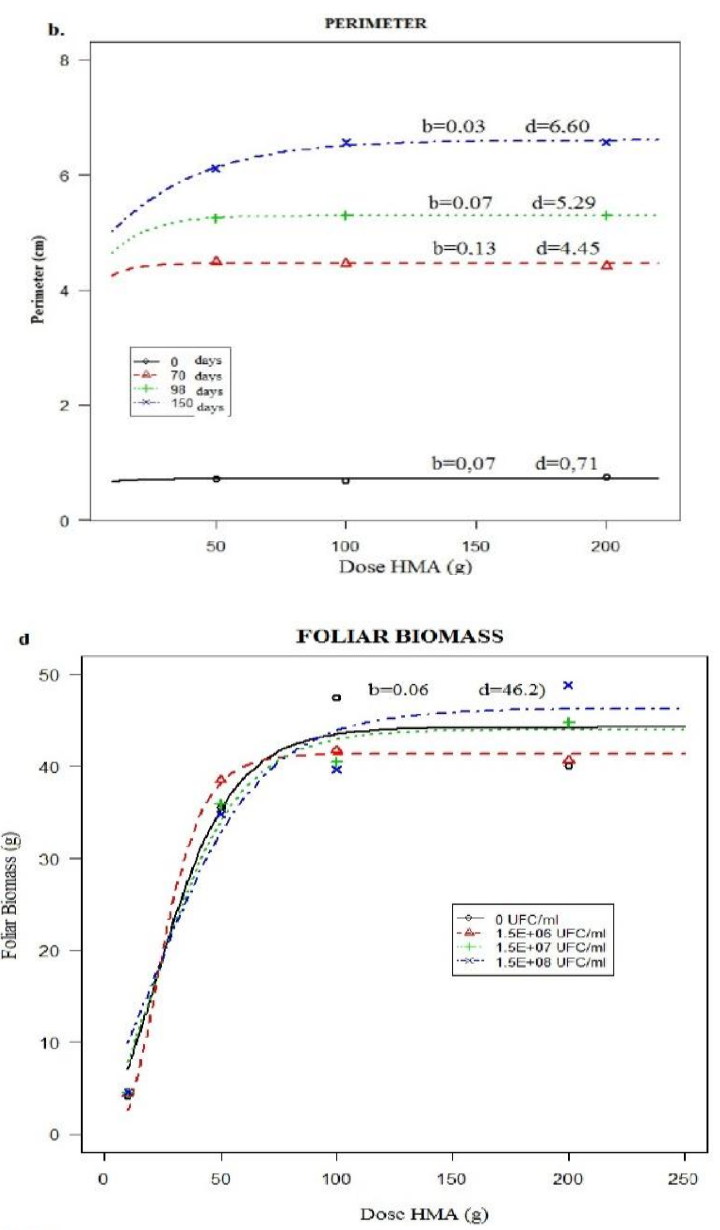

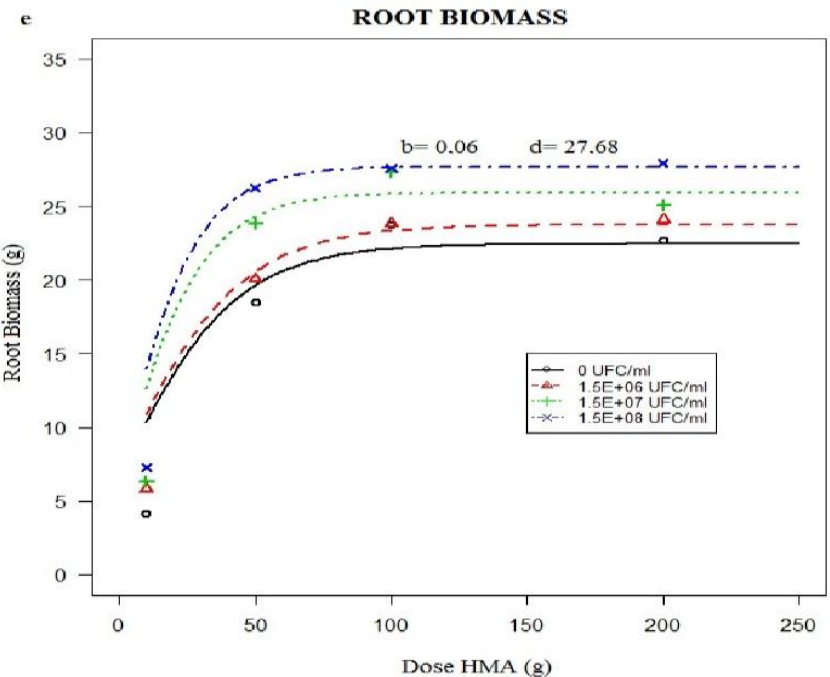

Fig. 3: Gompertz model for banana growth variables. a) Height b) Perimeter c) Leaf area d) Foliar biomass e) Root Biomass; Notation- b: slope d: upper limit. 


\section{Nutrient content Nitrogen}

In leaf tissue nitrogen content is above normal in all plants, since when HMA and bacteria nitrogen content increases, in the plant also increases, reaching highest value $(5.17 \%)$ when HMA $200 \mathrm{~g}$ and Azospirillum $10^{8} \mathrm{CFU} / \mathrm{ml}$ was applied (Figure $4 \mathrm{a}$ ).
Nitrogen content in soil inoculated with Azospirillum only increases when microorganism concentration is increased (Figure 5a). Furthermore the figure shows soil with HMA different doses and Azospirillum highest concentration, these soils presents higher nitrogen concentration, reaching its highest level (27.8 ppm) when $200 \mathrm{~g}$ and $10^{8} \mathrm{CFU} / \mathrm{ml}$ HMA is applied.

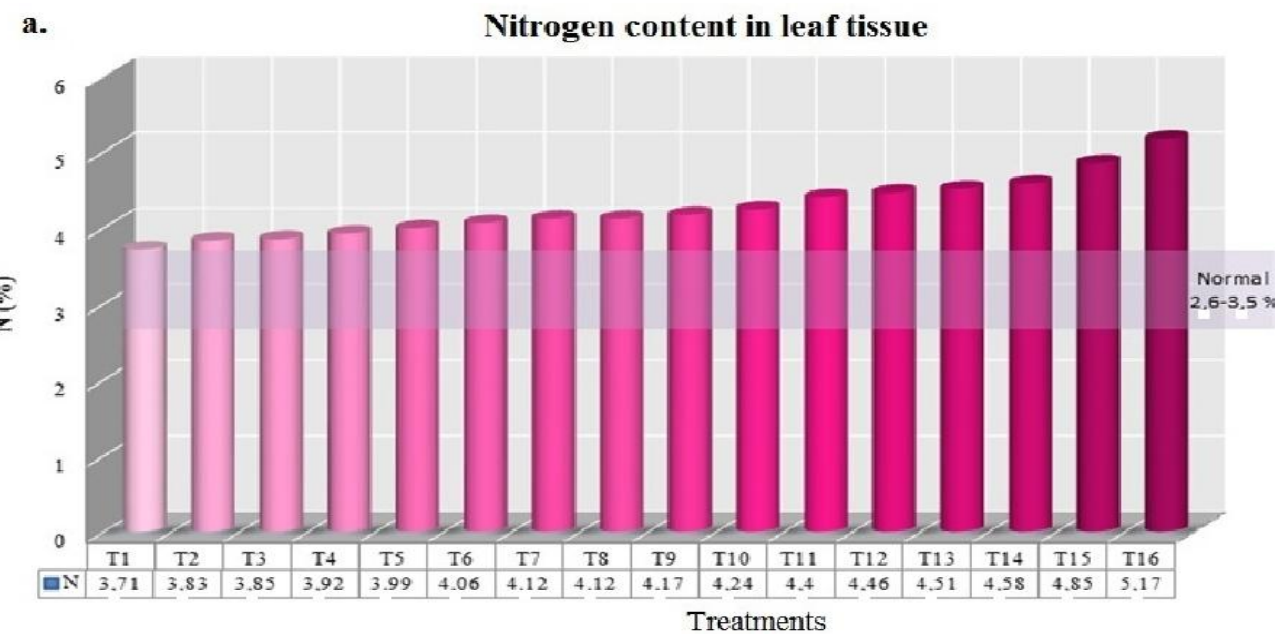

b.

Phosphorus content in leaf tissure

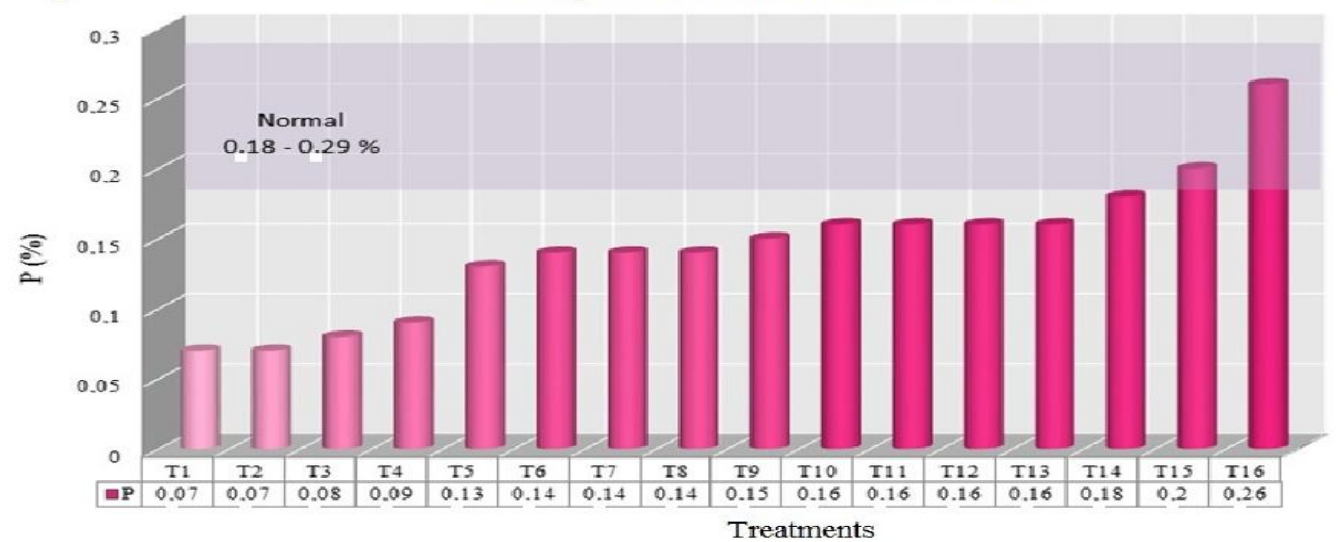

c.

Potassium content in leaf tissue

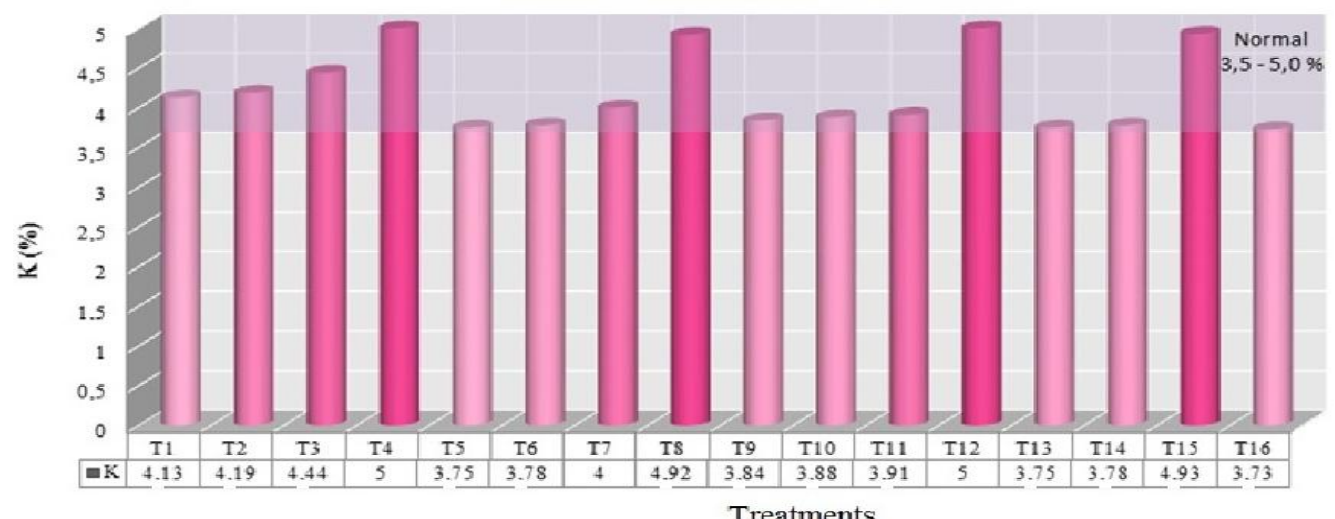

HMA dose treatments ( grams ): Azospirillum concentration ( CFU/ml ); T1 (0:0), T2 $\left(0: 10^{6}\right)$, T3 $\left(0: 10^{7}\right), \mathrm{T} 4\left(0: 10^{8}\right), \mathrm{T} 5(50: 0), \mathrm{T} 6\left(50: 10^{6}\right), \mathrm{T} 7\left(50: 10^{7}\right), \mathrm{T} 8$ $\left(50: 10^{8}\right)$, T9 $(100: 0)$, T10 $\left(100: 10^{6}\right)$, T11 $\left(100: 10^{7}\right)$, T12 $\left(100: 10^{8}\right)$, T13 $(200: 0)$, T14 $\left(200: 10^{6}\right)$, T15 $\left(200: 10^{7}\right)$, T16 $\left(200: 10^{8}\right)$.

Fig. 4: Effect of HMA and Azospirillum inoculation on nutrient content in leaf tissue. a) Nitrogen b) Phosphorus c) Potassium. 

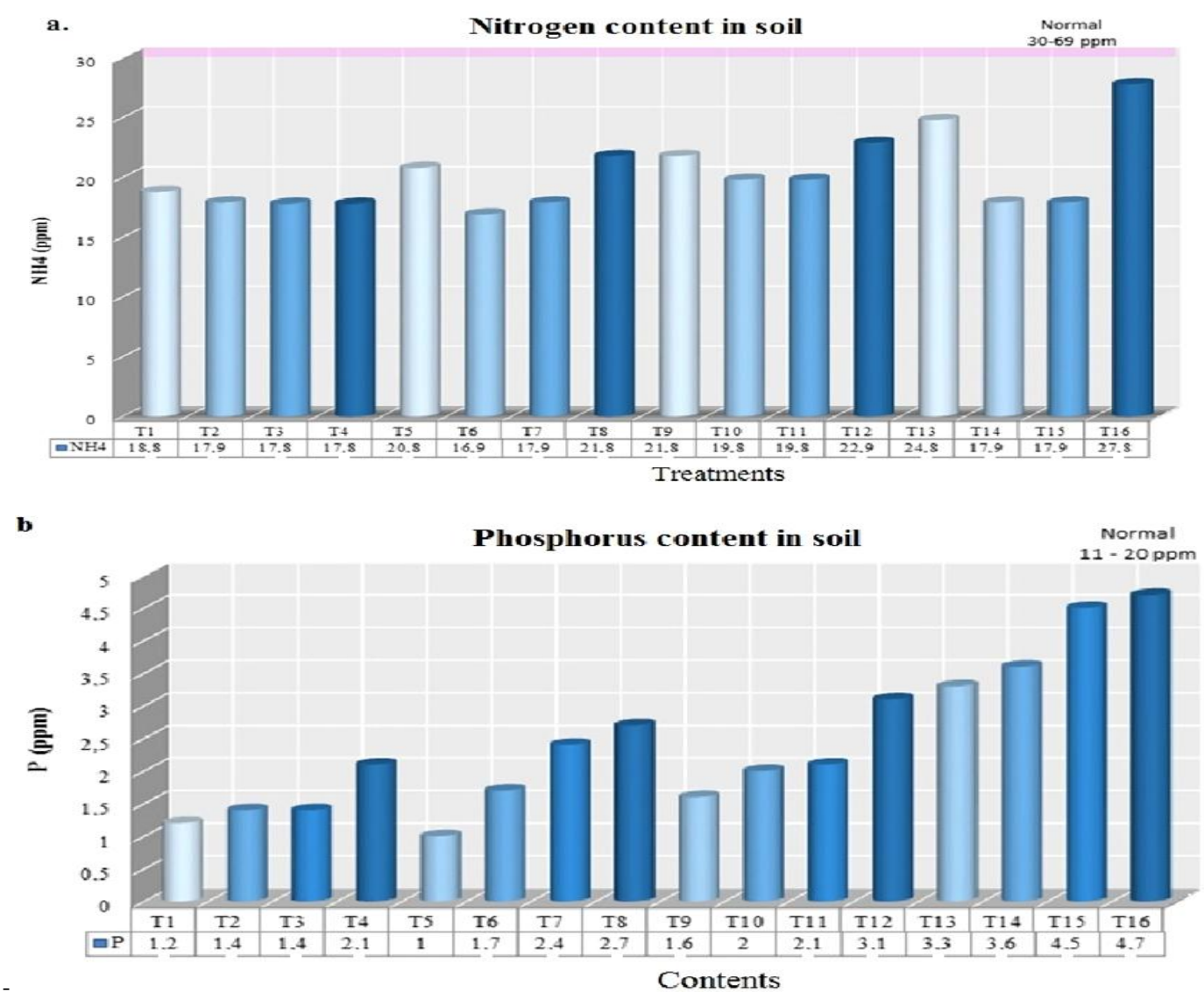

c

Potassium content in soil

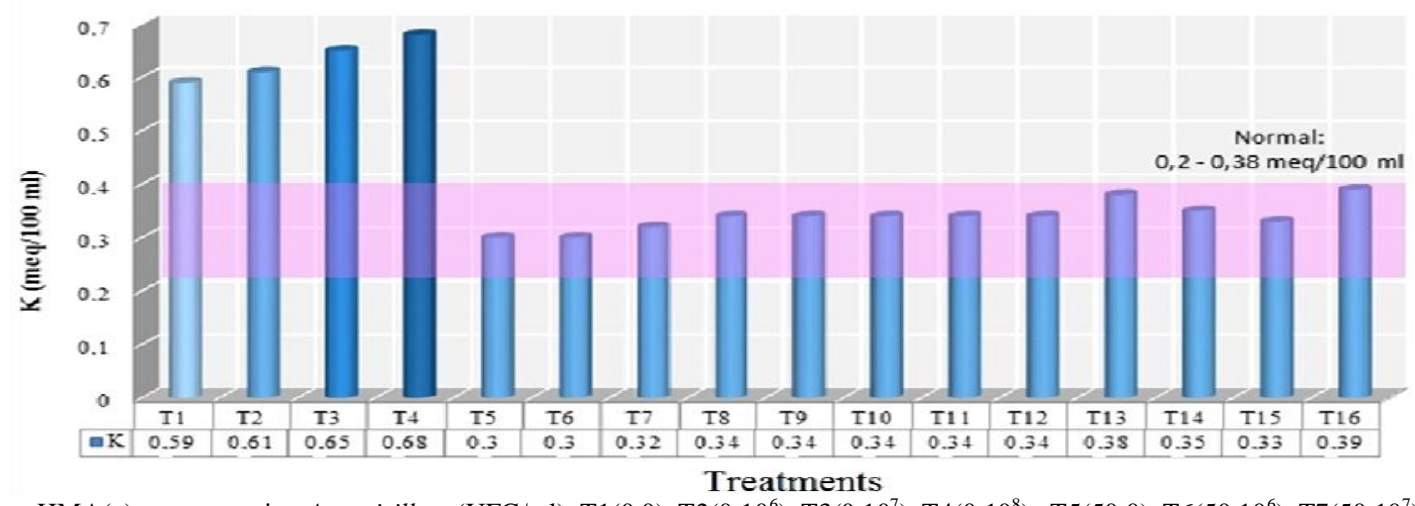

Treatment dose HMA(g): concentration Azospirillum (UFC/ml); T1(0.0), T2 $\left(0: 10^{6}\right)$, T3(0:10 $)$, T4 $\left(0: 10^{8}\right)$, T5 $(50: 0)$, T6 $\left(50: 10^{6}\right), \mathrm{T} 7\left(50: 10^{7}\right), \mathrm{T} 8\left(50: 10^{8}\right)$,

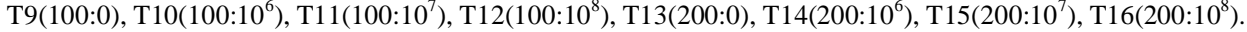

Fig. 5: Effect of HMA and Azospirillum inoculation on nutrient content in soil. a) Nitrogen b) Phosphorus c) Potassium.

\section{Phosphorus}

Fig. 4b shows low phosphorus levels in all plants, when HMA was increased, phosphorus reached the normal level when 200g HMA and Azospirillum $10^{8} \mathrm{CFU} / \mathrm{ml}$ was applied.

Regarding the content of phosphorus in soil (Figure 5b), although this element is below the normal range in all treatment, when HMA and Azospirillum dose increases, phosphorus soil content reaches higher levels when HMA (200 g) and Azospirillum $\left(10^{8} \mathrm{CFU} / \mathrm{ml}\right)$ maximum quantities were applied.

\section{Potassium}

The potassium content in leaf tissue (Figure 4c) showed a normal level in all plants, but by increasing Azospirillum concentration, a gradual potassium increase was registered, reaching values close to $5 \%$ when $10^{8} \mathrm{CFU} / \mathrm{ml}$ was inoculated. The potassium content in soil (Figure $5 \mathrm{c}$ ) showed normal values in all treatments, reaching higher values $(0.68 \mathrm{meq} / 100 \mathrm{ml})$ when $10^{8}$ $\mathrm{CFU} / \mathrm{ml}$ of Azospirillum were applied. 
Table 2: Effect of AMF and Azospirillum inoculation on increasing HMA spores final population.

\begin{tabular}{ccc}
\hline HMA $(\mathbf{g})$ & AZO $(\mathbf{U F C} / \mathbf{m l})$ & Spore population (spore/g) \\
\hline 200 & $1.50 \mathrm{E}^{8}$ & $62.67 \mathrm{a}$ \\
200 & $1.50 \mathrm{E}^{6}$ & $60.33 \mathrm{~b}$ \\
200 & $1.50 \mathrm{E}^{7}$ & $60.33 \mathrm{~b}$ \\
200 & 0 & $58.67 \mathrm{~b}$ \\
100 & $1.50 \mathrm{E}^{8}$ & $41.33 \mathrm{c}$ \\
100 & $1.50 \mathrm{E}^{6}$ & $40.33 \mathrm{c}$ \\
100 & 0 & $40.33 \mathrm{c}$ \\
100 & $1.50 \mathrm{E}^{7}$ & $40.00 \mathrm{c}$ \\
50 & $1.50 \mathrm{E}^{7}$ & $36.00 \mathrm{~d}$ \\
50 & $1.50 \mathrm{E}^{8}$ & $36.00 \mathrm{~d}$ \\
50 & $1.50 \mathrm{E}^{6}$ & $33.67 \mathrm{e}$ \\
50 & 0 & $32.33 \mathrm{e}$ \\
0 & $1.50 \mathrm{E}^{8}$ & $0.00 \mathrm{f}$ \\
0 & $1.50 \mathrm{E}^{7}$ & $0.00 \mathrm{f}$ \\
0 & $1.50 \mathrm{E}^{6}$ & $0.00 \mathrm{f}$ \\
0 & 0 & $0.00 \mathrm{f}$ \\
\hline
\end{tabular}

HMA: dose HMA, AZO: dose Azospirillum. In the same column, data with the same letter have no statistical differences according to Fisher LSD test at 5\% (p $\leq 0.05)$

\section{Mycorrhizal colonization percentage}

Mycorrhizal colonization was analyzed within cell cytoplasm roots of banana plantlets (Figure 6).

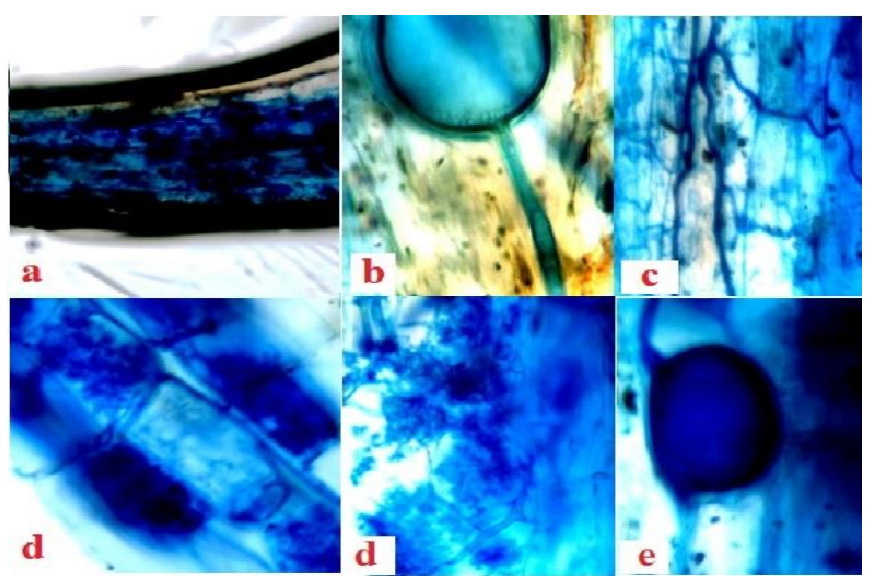

Fig. 6: HMA Structures found inside banana roots. a) HMA Root colonized, b) HMA Spore with supporting hyphae, c) Infective mycelial hyphae, d) Arbuscules HMA, e) Gall HMA.

Tabla 3. HMA inoculation effect and Azospirillum on mycorrhizal colonization percentage

\begin{tabular}{ccc}
\hline MA $(\mathbf{g})$ & AZO $(\mathbf{U F C} / \mathbf{m l})$ & \% colonization \\
\hline 200 & $1.50 \mathrm{E}^{8}$ & $96.67 \mathrm{a}$ \\
100 & $1.50 \mathrm{E}^{8}$ & $95.33 \mathrm{ab}$ \\
200 & $1.50 \mathrm{E}^{7}$ & $95.33 \mathrm{ab}$ \\
200 & 0 & $95.00 \mathrm{bc}$ \\
200 & $1.50 \mathrm{E}^{6}$ & $95.00 \mathrm{bc}$ \\
100 & $1.50 \mathrm{E}^{7}$ & $94.67 \mathrm{bc}$ \\
100 & 0 & $94.00 \mathrm{bc}$ \\
100 & $1.50 \mathrm{E}^{6}$ & $93.67 \mathrm{~cd}$ \\
50 & $1.50 \mathrm{E}^{8}$ & $92.33 \mathrm{de}$ \\
50 & $1.50 \mathrm{E}^{7}$ & $91.33 \mathrm{ef}$ \\
50 & $1.50 \mathrm{E}^{6}$ & $91.33 \mathrm{ef}$ \\
50 & 0 & $90.00 \mathrm{f}$ \\
0 & $1.50 \mathrm{E}^{8}$ & $0.00 \mathrm{~g}$ \\
0 & $1.50 \mathrm{E}^{7}$ & $0.00 \mathrm{~g}$ \\
0 & $1.50 \mathrm{E}^{6}$ & $0.00 \mathrm{~g}$ \\
0 & 0 & $0.00 \mathrm{~g}$ \\
\hline
\end{tabular}

HMA: dose HMA, AZO: dose Azospirillum
When HMA-Azospirillum interactions on colonization percentage (Table 3) was analyzed, it is observed that HMA (100 to $200 \mathrm{~g})$ higher doses treatment and Azospirillum $\left(10^{7}\right.$ and $10^{8}$ $\mathrm{CFU} / \mathrm{ml}$ ) highest concentrations, promote further increase in banana roots colonization. Additionally, the combined inoculation of two microorganisms, allows higher percentage of arbuscular mycorrhizal colonization, showing that these bacteria promote higher percentage of colonization up to $96.67 \%$ when $200 \mathrm{~g}$ HMA and $10^{8} \mathrm{CFU} / \mathrm{ml}$ Azospirillum was applied. In the same column, data with the same letter have no statistical differences according to Fisher LSD test at $5 \%(\mathrm{p} \leq 0.05)$

\section{Azospirillum final population}

Table 4 shows $\mathrm{T} 2$ to $\mathrm{T} 4$ treatments without HMA inoculated, the bacterial population in soil and roots is not increased. However, treatment with HMA 50, 100 and $200 \mathrm{~g}$ promote Azospirillum growth in roots and soil; all HMA doses promote bacterial growth.

Table 4. The final population of Azospirillum in the soil and banana roots.

\begin{tabular}{ccccc}
\hline TREATMENT & $\begin{array}{c}\text { MICO } \\
(\mathbf{g})\end{array}$ & $\begin{array}{c}\text { AZOS } \\
(\mathbf{U F C} / \mathbf{m l})\end{array}$ & $\begin{array}{c}\text { SOIL } \\
(\mathbf{U F C} / \mathbf{G})\end{array}$ & $\begin{array}{c}\text { ROOTS } \\
(\mathbf{U F C} / \mathbf{g})\end{array}$ \\
\hline T1 & 0 & 0 & 0 & 0 \\
T2 & 0 & $1.50 \mathrm{E}^{+6}$ & $9.00 \mathrm{E}^{+07}$ & $9.00 \mathrm{E}^{+06}$ \\
T3 & 0 & $1.50 \mathrm{E}^{+7}$ & $6.00 \mathrm{E}^{+07}$ & $3.3 \mathrm{E}^{+07}$ \\
T4 & 0 & $1.50 \mathrm{E}^{+8}$ & $9.00 \mathrm{E}^{+08}$ & $4.20 \mathrm{E}^{+08}$ \\
T5 & 50 & 0 & 0 & 0 \\
T6 & 50 & $1.50 \mathrm{E}^{+6}$ & $4.20 \mathrm{E}^{+08}$ & $9.00 \mathrm{E}^{+07}$ \\
T7 & 50 & $1.50 \mathrm{E}^{+7}$ & $3.45 \mathrm{E}^{+08}$ & $4.20 \mathrm{E}^{+09}$ \\
T8 & 50 & $1.50 \mathrm{E}^{+8}$ & $3.3 \mathrm{E}^{+09}$ & $4.20 \mathrm{E}^{+09}$ \\
T9 & 100 & 0 & 0 & 0 \\
T10 & 100 & $1.50 \mathrm{E}^{+6}$ & $4.20 \mathrm{E}^{+08}$ & $6.00 \mathrm{E}^{+07}$ \\
T11 & 100 & $1.50 \mathrm{E}^{+7}$ & $3.30 \mathrm{E}^{+08}$ & $4.20 \mathrm{E}^{+08}$ \\
T12 & 100 & $1.50 \mathrm{E}^{+8}$ & $3.45 \mathrm{E}^{+08}$ & $4.20 \mathrm{E}^{+09}$ \\
T13 & 200 & 0 & 0 & 0 \\
T14 & 200 & $1.50 \mathrm{E}^{+6}$ & $3.30 \mathrm{E}^{+08}$ & $4.20 \mathrm{E}^{+07}$ \\
T15 & 200 & $1.50 \mathrm{E}^{+7}$ & $7.50 \mathrm{E}^{+07}$ & $3.30 \mathrm{E}^{+08}$ \\
T16 & 200 & $1.50 \mathrm{E}^{+8}$ & $3.30 \mathrm{E}^{+09}$ & $4.95 \mathrm{E}^{+09}$ \\
\hline
\end{tabular}

The results described are due to a synergistic action which allows a significant increase in growth and nutrition of the host (Bashan et al., 1996). HMA action associated with further growth and development of banana plants inoculated contribute to the physiological function of the host plant, and allow assimilate easily the nutrients from the soil (Alarcon et al., 2000). Regarding Azospirillum, Bashan et al. (1996) states that auxin produced by this bacterial genus increase the number and length of lateral roots, increased root biomass accumulates, allow early development of root hairs, increase root surface area and stimulate root exudates. Root system transformation improves mineral absorption and increases development and plant nutrition. Bacteria and fungi interact having a positive effect on plant growth. The interaction between fungi and bacteria cause a positive effect on growth plants. This is related experimental evidence described by Russo et al. (2005) who observed that bacteria of Azospirillum genus were adhered to the surface of structures such as fungal mycelia, spores and colonized roots. This suggests that fungal structures can be used by bacteria as bridges to reach far into the epidermis radical 
(Bianciotto et al., 1996) layers. Furthermore, it is proposed that Azospirillum increases HMA-plant symbiosis because of phytohormones production that stimulate root branching. Tisserant et al. (1996) suggest that the physiological and enzymatically active mycelium is newly formed lateral roots; since HMAAzospirillum develop a functional interaction mycorrhizosphere (Barea et al., 2005). Finally, the increase in both microorganisms populations evidence a synergistic relationship. According to Packovsky et al., (1985) cortical cells penetration by HMA provide an entry route for Azospirillum resulting in bacterium population increase and facilitating their establishment and multiplication. According to Thimann (1979) Azospirillum hormones cause morphological changes in the root (increase in the number and length of roots) resulting in an increase of mycorrhizal colonization. In this experiment no adverse effects of microorganisms applied to banana plantlets development were observed, however Azospirillum and HMA inoculation increase growth and nutrition plants during acclimatization.

\section{CONCLUSIONS}

HMA and Azospirillum application (200 g $10^{8} \mathrm{cfu} / \mathrm{ml}$ respectively), allow greater growth and nutrition of micropropagated banana plantlets, registering increases of 7 times in height, 4 times in perimeter, 16 times in leaf area, 12 times in biomass and 8 times in root biomass, relative to control plants. The final microbial populations of both organisms are favored by coinoculation, reaching higher values with higher doses of each, which shows that HMA and Azospirillum combined application promotes mutual survival and multiplication and plant colonization.

\section{ACKNOWLEDGMENT}

The authors thank Dr Maria Soledad Ponce Benitez (Duke University) and Maize Program INIAP for their advice. This work was financially supported by HOLDINGDINE S.A. and Universidad de las Fuerzas Armadas-ESPE.

\section{Conflict Of Interests}

The authors declare that there is no conflict of interest regarding the publication of this paper.

\section{REFERENCES}

AEBE Association of Banana Exporters of Ecuador. 2010. Ecuador 's banana map. From: http://www.aebe.com.ec/Desktop. aspx?Id=47.

Alarcon, A. Ferrera-Cerrato, R. Gonzalez, M. C. and Villegas, A. Arbuscular mycorrhizal fungi in the dynamics of development of stolons and nutrition of strawberry plants FERN CV., Obtained by in vitro culture. TERRA Latinoamericana, 2010;18: 211-218.

Barea, J. Pozo, J. Azcón, R. Azcón-Aguilar, C. Microbial cooperation in the rhizosphere. J Exp Bot, 2005; 56: 1761-1778.

Bashan, Y and Holguin, G. Short medium terms avenues for Azospirillum inoculation. En Plant growth-promoting rhizobacteria-present status and future prospects. Sapporo: Hokkaido University, 1997a.

Bashan, Y and Holguin, G. Root-to-root travel of beneficial bacterium Azospirillum brasilense. Appl Environ Microbiol, 1997b;60: 21202131.
Bashan, Y. Holguin, G. Ferrera - Cerrato, R. Interactions between plants and beneficial microorganisms. I Azospirillum. Terra, 1996;14: 159-194

Bever, J. Morton, J. Antonovics, J and Schultz, P. Host dependent sporulation and species diversity of arbuscular mycorrhizal fungi in a mown grassland. J Ecology, 1996;84: 71-82.

Bianciotto, V. Bandi, D. Minerdi, M. Sironi, H. Tichy, P and Bonfante, P. An obligately endosymbiotic mycorrhizal fungus itself harbors obligately intracellular bacteria. Appl Environ Microbiol, 1996;62: 3005-3010.

Bolan, N. A critical review on the role of mycorrhizal fungi in the uptake of phosphorus by plants. Journal Plant and Soil, 1991;134: 189-207.

Crozier, A. Arruda, P. Jasmin, J. Monteiro, A and Sandberg, G. Analysis of indole-3-acetic acid and related indoles in culture medium from Azospirillum lipoferum and Azospirillum brasilense. Appl Environ Microbiol, 1998;54(11): 2233-2837.

Döbereiner, J. Marriel, I and Nery, M. Ecological destribution of Spirillum lipoferum Beijerinck. Can J Microbiol, 1976; 22: 1464-1473.

Gendermann, J and Nicholson, T. Spores of mycorrhizal Endogone species extracted from soil by wet, sieving and decanting. Trans Br Mycol Soc, 1963;46: 235-244.

Herrera, R. Furrazola, E. Ferrer, R. Fernández, R and Torres, Y. Functional strategies of root hairs and Arbuscular micorrhizhae in an evergreen tropical forest, Sierra del Rosario-Cuba. Revista CENIC Ciencias Biológicas, 2004;35: 113-123.

Jaizme-Vega, M.C. Rodríguez-Romero, A and Piñero-Guerra, M. Potential use of rhizobacteria from the Bacillus genus to stimulate the plant growth of micro propagated banana. Fruits, 2004;59: 83-90.

Loredo, O. Lopez, R and Espinosa, V. Review: plant growth promoting bacteria associated with grasses. Terra Latin America, 2004;22: 225-239.

Maldonado, J and Ramirez, G. 1997. Effect of inoculation with mycorrhizal fungi in coffee seedlings (Coffea arabica) Variety Colombia.

Okon, Y and Labandera-González, C. Agronomic applications of Azospirillum: An evaluation of 20 years worldwide field inoculation. Soil Biology and Biochemical, 1994;26(12): 1591-1601.

Pacovsky, R. Fuller, S and Paul, G. Influence of soil on the interactions between endo rhizosphere and Azospirillum in sorghum. Soil Biology and Biochemistry, 1985;17: 525-531.

Phillips, J and Hayman, D. Improve procedure of clearing roots and staining parasitic and vesicular-arbuscular mycorrhizal fungi for rapid assessment of infection. Trans. Br. Mycol. Soc, 1970; 55: 159-161.

Russo, A. Felici, C. Toffanin, A. Götz, M. Collados, C. Barea, J. Moënne-Loccoz, Y. Smalla, K. Vanderleyden, J and Nutri, M. Effect of Azospirillum inoculants on arbuscular mycorrhiza establishment in wheat and maize plants. Biology Fertility of Soils, 2005; 41(5): 301-309.

Thimann, K. Fifty years of plant hormone research. Plant Physiology, 1974;54: 450- 453.

Tien, T. Gaskins, M and Hubbell, D. Plant growth substances produced by Azospirillum brasilense and their effect on the growth of Pearl Millet (Pennisetum americanum L.). Appl Environ Microbiol, 1979; 37:10161024.

Tisserant, B. Gianinazzi, S and Gianinazzi-Pearson, V. Relationships between lateral root order, arbuscular mycorrhiza development, and the physiological state of the symbiotic fungus in Platanus acerifolia. Can J Bot, 1996;74:1947-1955.

\section{How to cite this article:}

Carina VT, Emilia MM, Miguel US, Ortiz DR, Manjunatha B, Thangaswamy S, Mulla SI. Effect of Arbuscular mycorrhizal fungi (AMF) and Azospirillum on growth and nutrition of banana plantlets during acclimatization phase. J App Pharm Sci, 2016; 6 (06): 131-138. 